\title{
BIM: A TECHNOLOGY ACCEPTANCE MODEL IN PERU
}

SUBMITTED: November 2019

REVISED: November 2019

PUBLISHED: February 2020 at https://www.itcon.org/2020/6

EDITOR: Turk Ž.

DOI: $10.36680 /$ j.itcon. 2020.006

Carlos Sanchís-Pedregosa, Associate professor

Faculty of Business, Universidad del Pacífico, Lima, Peru

Faculty of Economics and Business, Universidad de Sevilla, Sevilla, Spain

c.sanchisp@up.edu.pe

Juan-Manuel Vizcarra-Aparicio, Associate Researcher

Faculty of Civil Engineering, Universidad Nacional de San Antonio Abad del Cusco, Cusco, Peru juma_vi_ap@hotmail.com

Antonio L. Leal-Rodríguez, Associate professor

Faculty of Economics and Business, Universidad de Sevilla, Sevilla, Spain

aleal6@us.es

SUMMARY: The purpose of this paper is to empirically study factors that facilitate the adoption of building information modelling (BIM) among practitioners using the unified theory of technology acceptance model (TAM). The factors identified in the TAM were examined using a quantitative approach. The empirical investigation has been conducted using a survey questionnaire. The data set has been obtained from 73 architects and engineers in Peru. Results show that Perceived Usefulness (PU) is the most important determinant of Behavioural Intention (BI), while Perceived Ease of Use (PEOU) is found to have no significant effect on BI. The findings provide an excellent backdrop in the development of policy and a roadmap for BIM implementation in Peru. The original contribution and value of the paper is the use of TAM to provide empirical evidence on factors that facilitate BIM adoption in Peru.

KEYWORDS: BIM, TAM, Peru, AECO, Technology Management.

REFERENCE: Carlos Sanchís-Pedregosa, Juan-Manuel Vizcarra-Aparicio, Antonio L. Leal-Rodríguez (2020). BIM: a technology acceptance model in Peru. Journal of Information Technology in Construction (ITcon), Vol. 25, pg. 99-108, DOI: 10.36680/j.itcon.2020.006

COPYRIGHT: (C) 2020 The author(s). This is an open access article distributed under the terms of the Creative Commons Attribution 4.0 International (https://creativecommons.org/licenses/by/4.0/), which permits unrestricted use, distribution, and reproduction in any medium, provided the original work is properly cited. 


\section{INTRODUCTION}

Building Information Modelling (BIM) is one of the most transcendental changes in the Architectural, Engineering, Construction and Operations (AECO) sector as it is a technology providing a solution in the management of projects and its useful life (Galiano-Garrigós and Andújar-Montoya, 2018). Despite these benefits, the use of BIM is not the same extensive in countries all around the world. Specifically, European and North American countries have assumed this technological change very fast leading to a standard of BIM use. However, as stated by Hamma-adama and Kouider (2019), South American countries present a general misused of BIM: they are limited at design stage and show low level of maturity or knowledge on this regard.

Behind the reasons of that different trends among the regions are factors like legal and intellectual property issues ( $\mathrm{Lu}$ and Korman, 2010), resistance to change and cultural reasons ( $\mathrm{Gu}$ and London, 2010), lack of collaboration among those involved in the projects (Gurevich, Sacks and Shrestha, 2017), lack of training (Lee and Yu, 2017) and problems with software and hardware (Gilligan and Kunz, 2007). All of them are the typical factors pointed out when a new technology has to be accepted by a group of users. In Peru, BIM has been used for few national governmental projects with great success, e.g. the Pan American Games 2019 (Ministry of Economy and Finance, 2018). However, it can hardly be called a common practice at the Peruvian AECO sector.

To explain the central part of the innovations adaptation process, the Technology Acceptance Model (TAM) was developed by Davis (1989) and this has been adapted to several technological advances in different social contexts since 1989. To the date, TAM has been used to explain BIM acceptance in countries like Korea (Lee and Yu, 2016), China (Xu, Feng and Li, 2014), Ghana (Acquah, Eyiah and Oteng, 2018) and the UK (Ahmed and Kassem, 2018). These previous studies pointed out very different results among each context were was performed and there is no one in a South American country to the date.

Because of the above, this research aims to empirically test factors that facilitate the adoption of BIM in Peru using the unified theory of TAM. To do that, a data set of 73 Peruvian practitioners has obtained thanks to a survey adapted and distributed by the authors. Over that data set, PLS-SEM structural equation modelling was performed. To obtain the results which will drive to a series of conclusions. Next, the conceptual framework and hypotheses development are shown.

\section{CONCEPTUAL FRAMEWORK AND HYPOTHESES DEVELOPMENT}

There are plenty of definitions for BIM, but many of them came from software's companies that define BIM in accordance with their product's capabilities (Eastman et al., 2018). Taking BIM's definitions from a set of authors (Lee, Yu and Jeong, 2015; Azhar, 2011; Chen and Nguyen, 2016; López and Ballesteros, 2018; Bynum, Issa and Olbina, 2013) it could be said that BIM is an organized and collaborative workflow which is supported by digital technologies in order to generate and use data in the whole building's lifecycle (design, construction, facility management). Besides, BIM's benefits and its potential applications are not just limited for building's ones but also allows connection with IT (Information technology) and electronic technology. Therefore, it could be said that BIM allows collaboration with other outsides AECO industry disciplines. Table 1 shows a BIM's benefits and potential applications list.

Because of these benefits, there are many government and public organizations initiatives that try to introduce BIM in public projects. That is why BIM codes already exist in countries such as United States, United Kingdom, Norway, Denmark, Finland, Hong Kong, South Korea, Singapore, Spain and Chile (Gajendran and Le Goff, 2019; Lee and Yu, 2016; Lee and Yu, 2017; Gurevich, Sacks and Shrestha, 2017; CORFO, 2019). Nevertheless, BIM implementation in AECO Industry presents difficulties that generate lag in its standardization. Table 2 shows main problems in BIM implementations taken from many researches.

In order to explain the different level of innovations' adoption, Davis developed the Technology Acceptance Model (TAM) (Davis, 1989). This model is an adaptation taken from Theory of Reasoned Action (TRA) and the Theory of Planned Behaviour (TPB). Many researches use TAM as the main model to characterize the BIM acceptance that professionals show. In this line, one interesting research (Lee and $\mathrm{Yu}, 2017$ ) makes a comparison between AECO professionals from Korea and United States, which shows differences in the results of the hypotheses. Therefore, this research shows a cultural characterization, because it suggests that Korea is a collectivist society, whilst American society is an individualist society. Besides, one of the potential applications of BIM is the interaction with electronic technologies, that is why in Lee et al. (2012), it uses TAM model in order 
to understand users' behaviour of a BIM real-time model and smart sensor based tower crane navigation system for blind lifts. Also, Kim, Park and Chin (2015); and Xu, Feng and Li (2014) use a model which is the result of blending model TAM with external factors developed by the authors of the research, in order to characterize BIM acceptance in Korea and China. Finally, Ahmed and Kassem (2018) developed an own model based in United Kingdom BIM acceptance. It's important to highlight that the contribution of each research, although they are based on the same technology acceptance model, are the diverse external factors, which are different from each other; this is due to 2 circumstances: researcher's perspective and each society particularities. Because of that, Davis suggests that future researchers have to develop more own external factors, in order to have a better understanding of any complex social phenomenon (1989). Finally, Acquah et al. (2018) demonstrated that TAM model is useful in an African context to explain BIM acceptance factors.

\section{Table 1: BIM's benefits and potential applications}

\begin{tabular}{|c|c|c|}
\hline Description & Building Stage & Reference \\
\hline More precise and faster visualizations & Design & $\begin{array}{l}\text { Eastman et al. (2018); Lee, Yu and Jeong (2015), Azhar } \\
\text { (2011); Lee and Yu (2017) }\end{array}$ \\
\hline Allows energy, Ambient analysis (LEED) & Design & $\begin{array}{l}\text { Eastman et al. (2018); Lee, Yu and Jeong (2015); Azhar } \\
\text { (2011); Lee and Yu (2017); Chen and Nguyen (2016); López } \\
\text { and Ballesteros (2018); Bynum, Issa and Olbina (2013) }\end{array}$ \\
\hline Allows structural analysis & Design & $\begin{array}{l}\text { Eastman et al. (2018); López and Ballesteros (2018); Nielsen } \\
\text { and Madsen (2010). }\end{array}$ \\
\hline $\begin{array}{l}\text { Allows CFD (Computational Fluid Dynamics) } \\
\text { analysis }\end{array}$ & Design & Eastman (2018); López and Ballesteros (2018) \\
\hline Parametric modelling and automated assembly & Design & Eastman et al. (2018); Azhar (2011) \\
\hline & & Sacks (2004) \\
\hline Shortening of documents' errors and gap & Design & $\begin{array}{l}\text { Eastman et al. (2018); Lee, Yu and Jeong (2015); Azhar } \\
\text { (2011); Lee and Yu (2017); McGraw-Hill Construction (2012) }\end{array}$ \\
\hline $\begin{array}{l}\text { Allows coordination and collaboration between } \\
\text { disciplines }\end{array}$ & $\begin{array}{l}\text { Design and } \\
\text { Construction }\end{array}$ & Eastman et al. (2018); Azhar (2011) \\
\hline $\begin{array}{l}\text { Allows implementation of Lean Construction, and } \\
\text { PMBOK practices }\end{array}$ & Construction & Eastman et al. (2018) \\
\hline Allows interference and premature errors detection & Construction & $\begin{array}{l}\text { Eastman et al. (2018); Lee, Yu and Jeong (2015); Azhar } \\
\text { (2011); Lee and Yu (2017) }\end{array}$ \\
\hline Facility Management and building's operation & & $\begin{array}{l}\text { Eastman et al. (2018); Azhar (2011); Hamid and Alshawi } \\
\text { (2004) }\end{array}$ \\
\hline \multicolumn{2}{|c|}{$\begin{array}{l}\text { Allows develop and interaction with many technologies, such as } \\
\text { IoT(Internet of Things), augmented reality, virtual reality and smart } \\
\text { sensors. }\end{array}$} & Ahmed and Kassem (2018); Lee et al. (2012) \\
\hline \multicolumn{2}{|c|}{$\begin{array}{l}\text { Allows connection with many IT technologies, such as GIS } \\
\text { (Geographic Information Systems), databases (SQL, Excel) which are } \\
\text { related to the BigData guidelines. }\end{array}$} & $\begin{array}{l}\text { Ahmed and Kassem (2018); Lu, Lai and Tse (2019); Irizarry, } \\
\text { Karan and Jalaei (2013); Liu and Issa (2012) }\end{array}$ \\
\hline
\end{tabular}

Table 2: Researches of BIM adoption main problems

\begin{tabular}{ll}
\hline Description & References \\
\hline Resilience to change and cultural problems & Gu and London (2010); Hartmann and Fisher (2007); Xu, Feng and Li (2014); Kunz and \\
& Fisher (2012). \\
Lack of collaboration among project & Gu and London (2010); Gurevich, Sacks and Shrestha (2017); Lee and Yu (2017); Kim, \\
stakeholders & Park and Chin (2015); BIM Task Group (2011); Liu, Issa and Osbina (2010). \\
Legal and intellectual property problems & Lee and Yu (2017); Lee, Yu and Jeong (2015); Kim, Park and Chin (2015); BIM Task \\
& Group (2011). \\
Lack of training and direction in the use BIM & Gu and London (2010); Lee and Yu (2017); Gilligan and Kunz (2007); Lee, Yu and \\
and its regulations & Jeong (2015); BIM Task Group (2011); Building Cost Information Service (2011); \\
& Newton and Chileshe (2012). \\
Problems related to software and hardware & Lee, Yu and Jeong (2015); Gilligan and Kunz (2007); Lee and Yu (2017); BIM Task \\
& Group (2011). \\
\hline
\end{tabular}

As it was already pointed out, the goal of TAM is to predict users' acceptance of a technological innovation y explain their individual behaviour (Hameed and Counsell, 2012). Originally, the first TAM model developed by 
Davis (1989) has been evolving, since researchers have been enhancing and increasing external factors, arriving at TAM3 model developed by Venkatesh and Bala (2008) which we have consider to develop our conceptual model (Fig. 1).

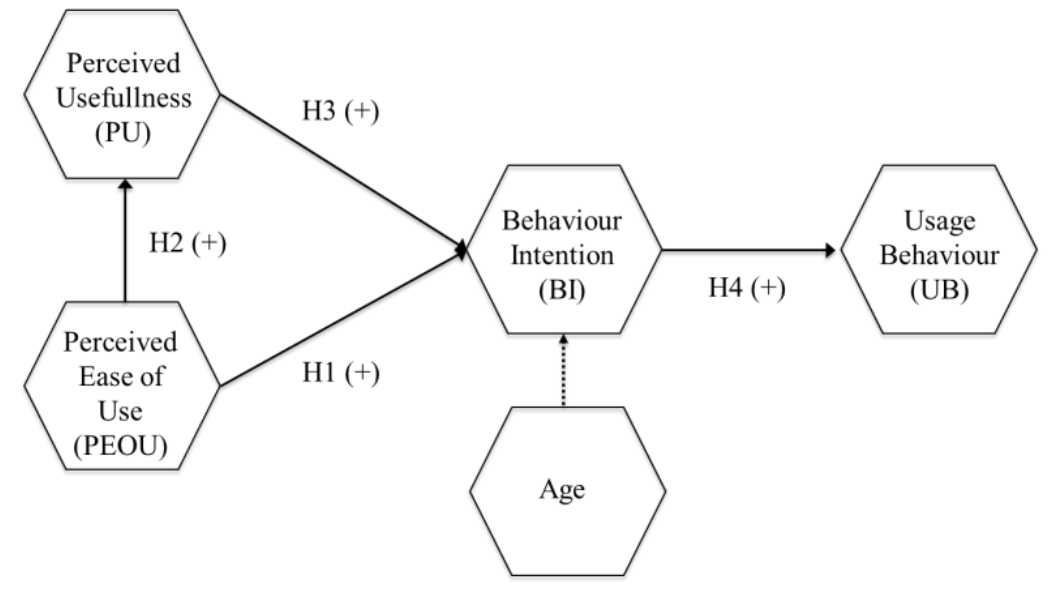

$$
\begin{aligned}
& \text { H5. PEOU } \rightarrow \text { PU } \rightarrow \text { BI } \\
& \text { H6. PEOU } \rightarrow \text { BI } \rightarrow \text { UB } \\
& \text { H7. PU } \rightarrow \text { BI } \rightarrow \text { UB }
\end{aligned}
$$

\section{FIG. 1: Conceptual model and hypotheses}

Firstly, TAM identifies 2 factors which are determinants of Behaviour Intention (BI) to use the new technology and this BI will drive to Usage Behaviour (UB). Perceived usefulness (PU) is defined as the extent to which a person believes that using the system will enhance job performance and Perceived Ease of Use (PEOU) which is defined as the extent to which a person believes that using the system will be free of effort (Lee, Yu and Jeong, 2015). Additionally, TAM3 identified PEOU like and antecedent to PU. Nevertheless, TAM assume the effect of external variables on BI. Because of that we introduced in our model the age of respondent like a key moderator as it was pointed out by Venkatesh et al. (2003). Finally, it is our aim to test every possible mediation effects among constructs. Therefore, our research hypotheses are:

H1. There is a positive relationship between PEOU and BI.

H2. There is a positive relationship between PEOU and PU.

$\mathrm{H} 3$. There is a positive relationship PU and BI.

H4. There is a positive relationship BI and UB.

H5. PU positively mediates the link between PEOU and BI.

H6. BI positively mediates the link between PEOU and UB.

H7. BI positively mediates the link between PU and UB.

\section{METHODOLOGY AND RESULTS}

To begin with the survey, it was designed adapting a BIM oriented previous one (Loyola, 2016) validated in Chile. This was due to that country has a similar cultural context as both countries, together with Colombia and Mexico, are part of the "Alianza del Pacífico" because of that similarities. The data set was collected thanks to an on-line survey send to the target group of respondents throw the Professional Associations of Architects and Engineers. Respondents must be active members of that associations which implies owning a university degree and a certain work experience. As a result, we were able to get a data set of 73 architects and engineers between 23 and 66 years' old who work in Peru. A broad descriptive analysis of the information collected is available in VizcarraAparicio (2018). 
Table 3: Survey questions

\begin{tabular}{|c|c|c|}
\hline Constructs & Indicators & Questions \\
\hline \multirow[t]{2}{*}{ Perceived Ease of Use } & PEOU1 & $\begin{array}{l}\text { Do you think that BIM adoption requires changes in your workflow practices } \\
\text { and processes? }\end{array}$ \\
\hline & PEOU2 & Do you think Peru is ready for BIM implementation? \\
\hline \multirow{3}{*}{ Perceived Usefulness } & PU1 & Do you think that BIM is the future of construction? \\
\hline & PU2 & Do you think universities should teach knowledge about BIM? \\
\hline & PU3 & Do you think there should be laws about the use of BIM? \\
\hline $\begin{array}{l}\text { Usage Behavior [Single- } \\
\text { item] }\end{array}$ & UB1 & What type of BIM user do you consider yourself? \\
\hline $\begin{array}{l}\text { Behavior Intention } \\
\text { [Single-item] }\end{array}$ & BI1 & How willing are you to using BIM? \\
\hline
\end{tabular}

This paper uses partial least squares (PLS-SEM) to assess the research model and hypotheses posited. PLS is a variance-based structural equation modeling technique that models and links concepts as latent variables or constructs approached though indicators or manifest variables (Roldán and Sánchez-Franco, 2012). This technique was chosen because the variables underlying the conceptual model are modelled as composite constructs. Plenty of conceptual and empirical studies recommend the use of PLS when a composite measurement model is supported (Rigdon, 2012; Henseler et al., 2014; Becker et al., 2013; Sarstedt, 2016. Additionally, this paper emphasizes the prediction of the dependent variables (Hair, Ringle and Sarstedt, 2011). Moreover, SmartPLS 3.2.7 software was used (Hair et al., 2014).

PLS models ought to be analyzed in two steps: (i) the assessment of the measurement model -the assessment of the reliability and validity of the measures- and (ii) the examination of the sign and significance of the structural relationships between the variables in the model -structural model assessment-.

Table 4 encompasses the main empirical results for the measurement model under assessment. The results are satisfactory for all the constructs within the model. On the one hand, PEOU is measured as a composite construct in Mode B. This implies that the outer weights and the existence of potential multicollinearity among the items should be assessed. It can be observed that PEOU1 (weight $=0.993$ ) majorly contributes to form the PEOU construct and that multicollinearity is not a concern in our paper, since all the VIF (variance inflation factor) values are well under the 3.3 threshold (Petter, Straub and Rai, 2007). On the other hand, PU is measured as a composite construct in Mode A. Hence, traditional tests for measuring internal consistency, reliability and validity might be applied (Henseler, Ringle and Sarstedt, 2015).

Table 4: Measurement model

\begin{tabular}{|c|c|c|c|c|c|c|}
\hline Construct/Indicator & $\begin{array}{l}\text { Outer } \\
\text { loadings }\end{array}$ & $\begin{array}{l}\text { Outer } \\
\text { weights }\end{array}$ & VIF & rho_A & $\begin{array}{l}\text { Composite } \\
\text { Reliability }\end{array}$ & AVE \\
\hline $\begin{array}{l}\text { Perceived Ease of Use } \\
\text { [Mode B composite] }\end{array}$ & & & & N/A & N/A & N/A \\
\hline PEOU1 & & 0.993 & 1.030 & & & \\
\hline PEOU2 & & 0.037 & 1.030 & & & \\
\hline $\begin{array}{l}\text { Perceived Usefulness } \\
\text { [Mode A composite] }\end{array}$ & & & & 0.729 & 0.799 & 0.578 \\
\hline PU1 & 0.548 & & 1.346 & & & \\
\hline PU2 & 0.821 & & 1.274 & & & \\
\hline PU3 & 0.872 & & 1.635 & & & \\
\hline Usage Behavior [Single-item] & & & & 1.000 & 1.000 & 1.000 \\
\hline UB & 1.000 & & 1.000 & & & \\
\hline Behavior Intention [Single-item] & & & & 1.000 & 1.000 & 1.000 \\
\hline BI & 1.000 & & 1.000 & & & \\
\hline Age [Single item] & & & & 1.000 & 1.000 & 1.000 \\
\hline Age & 1.000 & & 1.000 & & & \\
\hline
\end{tabular}

Note: N/A: Not applicable; Rho_A: Dijkstra-Henseler's indicator; AVE: average variance extracted 
First, the indicators' outer loadings are generally above the 0.707 critical level. However, one of them (PU1) is marginally below this threshold. Thus, we chose to keep it to maintain the content validity of the scale. We had to delete the item PU2 item, given that its outer loading (0.048) was too low. Therefore, individual item reliability is considered satisfactory in this study. Besides, the requisite of construct-level reliability is also complied, since the values observed for the Dijkstra-Henseler's indicator (Rho_A) and composite reliability surpass the 0.7 threshold. In addition, convergent validity is also attained, given that the average variance extracted (AVE) value surpass the 0.5 cut-off. Finally, Table 5 discloses that the variables reach discriminant validity accordingly with both the Fornell-Larcker and the Heterotrait-Monotrait (HTMT) approaches (Henseler, Ringle and Sarstedt, 2015). This implies that the variables constructs are significantly different between each other. With regard to BI and UB, both are modelled as single-item variables.

Table 5: Discriminant validity

\begin{tabular}{ccccc}
\hline \multicolumn{5}{c}{ Fornell-Larcker criterion } \\
\hline BI & PEOU & PU & UB \\
\hline BI & $\mathbf{1 . 0 0 0}$ & & & \\
PEOU & 0.044 & $\mathbf{0 . 7 2 2}$ & & \\
PU & 0.307 & 0.310 & $\mathbf{0 . 7 6 0}$ & $\mathbf{1 . 0 0 0}$ \\
UB & 0.804 & 0.013 & 0.259 & UB \\
\hline \multicolumn{5}{c}{ Heterotrait-Monotrait Ratio (HTMT) criterion } \\
\hline BI & BI & PEOU & PU & \\
PEOU & 0.073 & & & \\
PU & 0.357 & 0.538 & & \\
UB & 0.804 & 0.052 & 0.355 &
\end{tabular}

Note: Fornell-Larcker criterion: Diagonal elements (in bold) are the square root of the AVE values. namely the square root of the variance shared between constructs and its measures. whereas off-diagonal elements are the latent variable correlations. To attain discriminant validity. off-diagonal elements should never surpass diagonal elements. In accordance with the Heterotrait-Monotrait Ratio (HTMT) criterion all the values should be under the critical level of 0.85 (Kline, 2015).

According to Hair et al. (2011), a 5,000 resamples bootstrapping procedure was computed to generate the tstatistics, p-values, standard errors, and 95\% BCCI (bias corrected confidence intervals) that permit the examination of the sign and significance of the relationships hypothesized in the research model. Table 6 encompasses the main structural model results. PLS-SEM uses the coefficient of determination ( $\mathrm{R}_{2}$ coefficient) as the main criterion to examine the amount of explained variance of the dependent variables. Hence, the results comprised in Table 6 validate the structural model that this paper posits, since they show that it offers satisfactory predictive power for the endogenous constructs.

Table 6: Structural model results

\begin{tabular}{lllllll}
\hline & \multicolumn{2}{c}{ R 2 PU $=0.096 ; \mathrm{R}_{2 \mathrm{BI}}=0.097 ; \mathrm{R}_{2 \mathrm{UB}}=0.647$} & \multicolumn{3}{c}{$95 \%$ BCCI } & Statistical Support \\
\hline Direct effects & Patch coefficient & T Statistics & P-Value & $5.0 \%$ & $95.0 \%$ & \\
\hline PEOU $\rightarrow$ BI & $-0.057 \mathrm{~ns}$ & 0.422 & 0.337 & -0.281 & 0.152 & No \\
PEOU $\rightarrow$ PU & $0.310 \mathrm{~ns}$ & 1.524 & 0.064 & -0.325 & 0.525 & No \\
PU $\rightarrow$ BI & $0.325 *$ & 2.177 & 0.015 & -0.015 & 0.512 & Yes \\
BI $\rightarrow$ UB & $0.804 * * *$ & 43.437 & 0.000 & 0.773 & 0.833 & Yes \\
\hline Indirect effects & Patch coefficient & T Statistics & P-Value & $5.0 \%$ & $95.0 \%$ & \\
\hline PEOU $\rightarrow$ PU $\rightarrow$ BI & $0.101 \mathrm{~ns}$ & 1.174 & 0.120 & -0.055 & 0.229 & No \\
PEOU $\rightarrow$ BI $\rightarrow$ UB & $0.035 \mathrm{~ns}$ & 0.344 & 0.366 & -0.155 & 0.175 & No \\
PU $\rightarrow$ BI $\rightarrow$ UB & $0.261 *$ & 2.200 & 0.014 & -0.011 & 0.411 & Yes \\
[control vble]: & $-0.297 * *$ & 2.413 & 0.016 & -0.532 & -0.053 & Yes \\
AGE $\rightarrow$ BI & & & & & & \\
\hline
\end{tabular}


Note: $95 \%$ BCCI: Bootstrapping 95\% bias corrected confidence intervals in square brackets (based on $\mathrm{n}=5,000$ subsamples). ***p b $.001 ; * *$ p b $.01 ; *$ p b .05 (based on $\mathrm{t}(4999)$. one-tailed test). $\mathrm{t}(0.05 .4999)=1.645 ; \mathrm{t}(0.01$. 4999) $=2.327 ; \mathrm{t}(0.001 .4999)=3.092 ; \mathrm{ns}:$ not significant.

Additionally, two of the direct effects ( $\mathrm{PU} \rightarrow \mathrm{BI}$ and BI $\rightarrow \mathrm{UB}$ ) hypothesized in the conceptual model are revealed positive and significant, whereas the two other direct links posited (PEOU $\rightarrow \mathrm{BI}$ and PEOU $\rightarrow$ PU) are found to be non-significant. This work also finds support for the existence of an indirect (mediation) effect of PU on UB via BI (PU $\rightarrow$ BI $\rightarrow$ UB), while the other two indirect effects hypothesized (PEOU $\rightarrow$ PU $\rightarrow$ BI and PEOU $\rightarrow$ BI $\rightarrow$ UB) are shown to be non-significant. Finally, a negative significant effect of the external variable analysed (age) over BI was found. To a complete understanding of these findings, our research model is presented with the results of our hypothesis tests (Fig. 2).

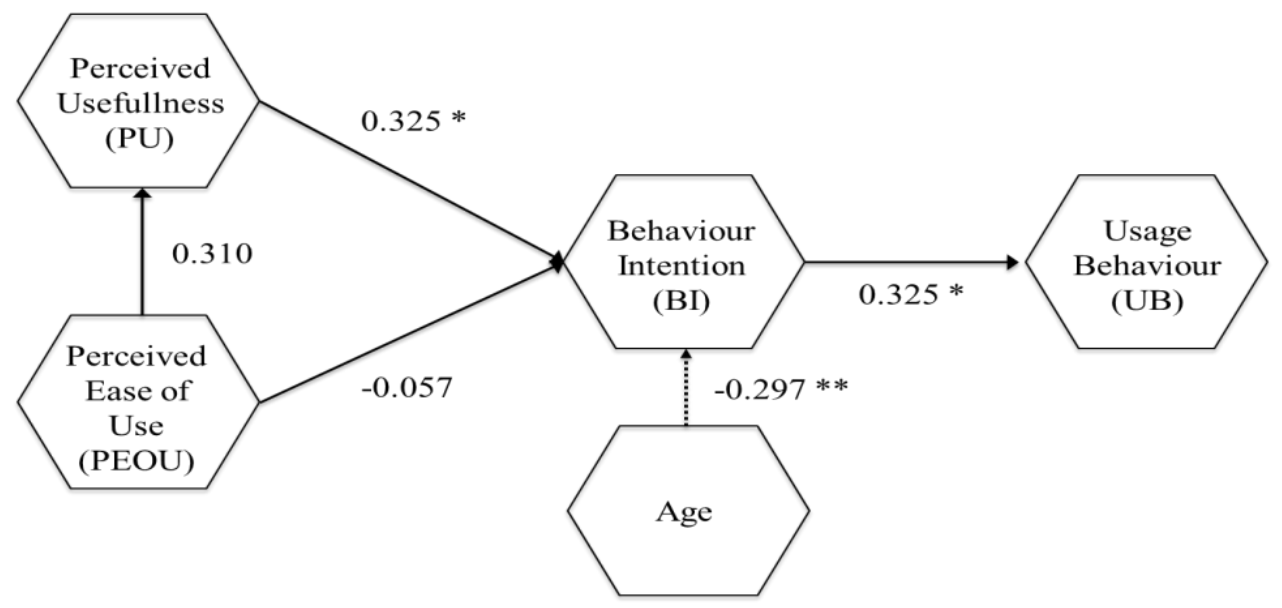

H5. PEOU $\rightarrow$ PU $\rightarrow$ BI : 0.101

H6. PEOU $\rightarrow$ BI $\rightarrow$ UB : 0.035

H7. PU $\rightarrow$ BI $\rightarrow$ UB : $0.261^{*}$

FIG 2.: Research model and hypothesis test results.

\section{DISCUSSION AND CONCLUSSIONS}

In line with previous literature, this research analyses the determinants of BIM acceptance in Peru. With this aim, TAM3 was assumed as a conceptual model, like other authors already did in different contexts. Results have shown that Perceived Usefulness (PU) is the most important driver to predict Behavioural Intention (BI) instead of Perceived Ease of Use (PEOU). These results are in line with similar studies analysing BIM acceptance in other countries. That is the case of China, were PU happened to be a primary determinant as well (Xu, Feng \& Li, 2014). This is similar to the results obtained by Wu et al. (2016), where experts had high levels of PU that influence high levels of BI as well. The same author also stated no significant connection between PEOU and BI for both cases, experts and novices. However, Xu, Feng \& Li (2014) states PEOU has an important effect as well, different to our findings. It's important to highlight that $\mathrm{Xu}$, Feng \& $\mathrm{Li}(2014)$ based their results on participants with considerable expertise on the BIM use, whine $\mathrm{Wu}$ et al. (2016) ran a study with novice and experts at the construction field in general.

Our results demonstrated that PEOU is not a significant determinant of the BIM in the Peruvian context, as it was found in the case of Korea (Son, H. Lee S. \& Kim, 2015; Le, Yu \& Jeong, 2015). Moreover, as the general TAM theory establishes, a significant relation between $\mathrm{BI}$ and UB is supported. This means that the intention to use BIM leads to the actual use of the system in the Peruvian case. Additionally, related to the mediation effects, only BI seems to have an effect between PU and UB. Finally, the age of respondent seems to be a barrier of BIM implementation as a negative relation of that construct has been demonstrated. However, this is not an unexpected finding since previous research has identified such as negative correlation between technology acceptance and age (Tam, 2014). 
Therefore, these results can be used to develop a BIM acceptance strategy by Peruvian government and other institutions persecuting its massive implementation on the country. That strategy would consider that PU is the key factor to adopt BIM among AECO professionals, so communications and learning tools must consider this as a central point.

Regarding limitations on this research, it is important to note the focus on a single country so there is a need to test the TAM model for BIM in other south American nations in order to determine if these results could be generalized. It could also be interesting would be to replicate the study in different countries of the region in order to assess if there is a representative pattern based on contextual variables. Finally, there are other expanded TAM conceptual frameworks that can be tested to get a broader number of items to analyse. This is considered a limitation of TAM, specifically regarding its simplicity and abstractness Ajibade (2018), however our research finding represent a precedent to settle a baseline to elaborate on a more holistic theory of BIM acceptance.

\section{REFERENCES}

Acquah, R., Eyiah, A. K., \& Oteng, D. (2018). Acceptance of building information modelling: A survey of professionals in the construction industry in Ghana. Journal of Information Technology in Construction.

Ahmed, A. L., \& Kassem, M. (2018). A unified BIM adoption taxonomy: Conceptual development, empirical validation and application. Automation in Construction. https://doi.org/10.1016/j.autcon.2018.08.017

Ajidabe, P. (2018). Technology Acceptance Model Limitations and Criticisms: Exploring the Practical Applications and Use in Technology-related Studies, Mixed-method, and Qualitative Researches. Library Philosophy and Practice (e-journal). 1941. http://digitalcommons.unl.edu/libphilprac/1941

Azhar, S. (2011). Building information modeling (BIM): Trends, benefits, risks, and challenges for the AEC industry. Leadership and Management in Engineering. https://doi.org/10.1061/(ASCE)LM.19435630.0000127

Becker, J. M., Rai, A., Ringle, C. M., \& Völckner, F. (2013). Discovering unobserved heterogeneity in structural equation models to avert validity threats. MIS Quarterly: Management Information Systems. https://doi.org/10.25300/MISQ/2013/37.3.01

BIM Industry Working Group. (2011). A report for the Government Construction Client Group - March 2011. Department of Business, Innovation and Skills. https://doi.org/10.1524/teme.2010.0045

Building Cost Information Service. (2011). RICS 2011 Building Information Modelling Survey Report. In Building.

Bynum, P., Issa, R. R. A., \& Olbina, S. (2013). Building information modeling in support of sustainable design and construction. Journal of Construction Engineering and Management. https://doi.org/10.1061/(ASCE)CO.1943-7862.0000560

Chen, P. H., \& Nguyen, T. C. (2016). Integrating BIM and Web Map Service (WMS) for Green Building Certification. Procedia Engineering. https://doi.org/10.1016/j.proeng.2016.11.651

CIFE. (2007). VDC Use in 2007: Significant Value, Dramatic Growth, and Apparent Business Opportunity. Center For Integrated Facility Engineering.

CORFO. (n.d.). Methodologies and Technologies for a Collaborative Construction. Retrieved from Planbim website: http://planbim.cl/wp-content/uploads/2018/06/folleto-planbim.pdf

Eastman, C., Teicholz, P., Sacks, R., \& Liston, K. (2008). A Guide to Building Information Modeling for Owners, Managers, Designers. Wiley Interscience.

es.BIM. (2019). Observatorio es.BIM. Sexto Informe. Retrieved from https://www.esbim.es/wpcontent/uploads/2019/02/Informe_Observatorio_esBIM_Diciembre.pdf

Gajendran, T., Brewer, G., \& Le Goff, R. (2012). Building Information Modelling (BIM): an Introduction and International Perspectives. https://doi.org/10.13140/RG.2.2.13634.58565

Galiano-Garrigós, A., \& Andújar-Montoya, M. D. (2018). Building information modelling in operations of maintenance at the university of alicante. International Journal of Sustainable Development and Planning. https://doi.org/10.2495/SDP-V13-N1-1-11 
Gu, N., \& London, K. (2010). Understanding and facilitating BIM adoption in the AEC industry. Automation in Construction. https://doi.org/10.1016/j.autcon.2010.09.002

Gurevich, U., Sacks, R., \& Shrestha, P. (2017). BIM adoption by public facility agencies: impacts on occupant value, Building Research \& Information. Building Research \& Information. https://doi.org/10.1080/09613218.2017.1289029

Hair, J. F., Ringle, C. M., \& Sarstedt, M. (2011). PLS-SEM: Indeed a silver bullet. Journal of Marketing Theory and Practice. https://doi.org/10.2753/MTP1069-6679190202

F. Hair Jr, J., Sarstedt, M., Hopkins, L., \& G. Kuppelwieser, V. (2014). Partial least squares structural equation modeling (PLS-SEM) An emerging tool in business research. European Business Review, 26(2), 106-121. https://doi.org/10.1108/EBR-10-2013-0128

Hameed, M. A., Counsell, S., \& Swift, S. (2012). A conceptual model for the process of IT innovation adoption in organizations. Journal of Engineering and Technology Management - JET-M. https://doi.org/10.1016/j.jengtecman.2012.03.007

Hamid, Z. A., \& Alshawi, M. (2004). Role of Information Technology in Facility Management. Buletin Ingenieur, (24), 25-31.

Hamma-adama, M., \& Kouider, T. (2019). Comparative Analysis of BIM Adoption Efforts by Developed Countries as Precedent for New Adopter Countries. Current Journal of Applied Science and Technology. https://doi.org/10.9734/cjast/2019/v36i230224

Hartmann, T., \& Fischer, M. (2008). Applications of BIM and Hurdles for Widespread Adoption of BIM 2007 AISC-ACCL eConsttruction Roundtable Event Report. BIM-Legal.

Henseler, J., Dijkstra, T. K., Sarstedt, M., Ringle, C. M., Diamantopoulos, A., Straub, D. W., ... Calantone, R. J. (2014). Common Beliefs and Reality about Partial Least Squares: Comments on Rönkkö \& Evermann (2013),. Organizational Research Methods.

Henseler, J., Ringle, C. M., \& Sarstedt, M. (2014). A new criterion for assessing discriminant validity in variancebased structural equation modeling. Journal of the Academy of Marketing Science. https://doi.org/10.1007/s11747-014-0403-8

Irizarry, J., Karan, E. P., \& Jalaei, F. (2013). Integrating BIM and GIS to improve the visual monitoring of construction supply chain management. Automation in Construction. https://doi.org/10.1016/j.autcon.2012.12.005

Kim, S., Park, C. H., \& Chin, S. (2016). Assessment of BIM acceptance degree of Korean AEC participants. KSCE Journal of Civil Engineering. https://doi.org/10.1007/s12205-015-0647-y

Kline., R.Kline., R. B. (2015). P. and practice of structural equation modeling. G. publications. B. (2015). Principles and Practice of Structural Equation Modeling 3nd edition.pdf. Guilford Publications.

Kunz, J., \& Fischer, M. (2012). Virtual Design and Construction: Themes, Case Studies and Implementation Suggestions. CIFE Working Paper.

Lee, G., Cho, J., Ham, S., Lee, T., Lee, G., Yun, S. H., \& Yang, H. J. (2012). A BIM- and sensor-based tower crane navigation system for blind lifts. Automation in Construction. https://doi.org/10.1016/j.autcon.2012.05.002

Lee, S., \& Yu, J. (2017). Discriminant model of BIM acceptance readiness in a construction organization. KSCE Journal of Civil Engineering. https://doi.org/10.1007/s12205-016-0555-9

Lee, S., \& Yu, J. (2016). Comparative Study of BIM Acceptance between Korea and the United States. Journal of Construction Engineering and Management. https://doi.org/10.1061/(ASCE)CO.1943-7862.0001076

Lee, S., Yu, J., \& Jeong, D. (2015). BIM acceptance model in construction organizations. Journal of Management in Engineering. https://doi.org/10.1061/(ASCE)ME.1943-5479.0000252

Liu, R., \& Issa, R. R. A. (2012). 3D visualization of sub-surface pipelines in connection with the building utilities: Integrating GIS and BIM for facility management. Congress on Computing in Civil Engineering, Proceedings. https://doi.org/10.1061/9780784412343.0043 
Liu, R., Issa, R. R. a, \& Olbina, S. (2010). Factors influencing the adoption of building information modeling in the AEC Industry. Proceedings of the International Conference on Computing in Civil and Building Engineering.

López, A., \& Ballesteros, J. M. (2018). Modelado BIM. Simulación computacional en el proyecto constructivo hospitalario. Hospitecnia: Revista de Arquitectura, Ingeniería, Gestión Hospitalaria y Sanitaria, 13-22.

Loyola, M. (2016). National survey of BIM 2016: Results.

Lu, N., \& Korman, T. (2010). Implementation of Building Information Modeling (BIM) in Modular Construction: Benefits and challenges. Construction Research Congress 2010: Innovation for Reshaping Construction Practice - Proceedings of the 2010 Construction Research Congress. https://doi.org/10.1061/41109(373)114

Lu, W., Lai, C. C., \& Tse, T. (2018). BIM and Big Data for Construction Cost Management. https://doi.org/10.1201/9781351172325

McGraw Hill Construction. (2012). The Business Value of BIM in North America: Multi-Year Trend Analysis and User Ratings (2007-2012). In SmartMarket Report.

Ministry of Economy and Finance (2018, August). Government will implement work methodology to improve the management and reduction of costs and deadlines of public investment projects. Retrieved from https://bit.ly/33CTfdF

Newton, K., \& Chileshe, N. (2012). Awareness, usage and benefits of building information modelling (BIM) adoption - The case of the South Australian construction organisations. Association of Researchers in Construction Management, ARCOM 2012 - Proceedings of the 28th Annual Conference.

Nielsen, A. K., \& Madsen, S. (2010). Structural modelling and analysis using BIM tools. Retrieved from https://projekter.aau.dk/projekter/files/32688467/Structural-modelling-and-analysis-using-BIM-tools.pdf

Petter, S., Straub, D., \& Rai, A. (2007). Specifying formative constructs in information systems research. MIS Quarterly: Management Information Systems.

Rigdon, E. E. (2012). Rethinking Partial Least Squares Path Modeling: In Praise of Simple Methods. Long Range Planning. https://doi.org/10.1016/j.lrp.2012.09.010

Roldán, J. L., \& Sánchez-Franco, M. J. (2012). Variance-based structural equation modeling: Guidelines for using partial least squares in information systems research. In Research Methodologies, Innovations and Philosophies in Software Systems Engineering and Information Systems. https://doi.org/10.4018/978-14666-0179-6.ch010

Sacks, R. (2004). Evaluation of economic impact of three-dimensional modeling in precast concrete engineering. Journal of Computing in Civil Engineering. https://doi.org/10.1061/(ASCE)0887-3801(2004)18:4(301)

Sarstedt, M., Hair, J. F., Ringle, C. M., Thiele, K. O., \& Gudergan, S. P. (2016). Estimation issues with PLS and CBSEM: Where the bias lies! Journal of Business Research. https://doi.org/10.1016/j.jbusres.2016.06.007

Son, H., Lee, S., \& Kim, C. (2015). What drives the adoption of building information modeling in design organizations? An empirical investigation of the antecedents affecting architects' behavioral intentions. Automation in Construction. https://doi.org/10.1016/j.autcon.2014.10.012

Tams S., Grover V., \& Thatcher J. (2014). Modern information technology in an old workforce: toward a strategic research agenda, The Journal of Strategic Information Systems, Vol. 23, No. 4, 284-304. https://10.1016/j.jsis.2014.10.001.

Venkatesh, V., Morris, M.G., Davis, F.D., \& Davis, G.B. (2003). User Acceptance of Information Technology: Toward a Unified View. MIS Quarterly, 27, 425-478. https://www.jstor.org/stable/30036540

Venkatesh, V., \& Bala, H. (2008). Technology acceptance model 3 and a research agenda on interventions. Decision Sciences. https://doi.org/10.1111/j.1540-5915.2008.00192.x

Vizcarra-Aparicio, J. M. (2018). Regional report of Building Information Modeling (BIM). Cusco.

Wu, Y. W., Wen, M. H., Chen, C. M., \& Hsu, I. T. (2016). An integrated BIM and cost estimating blended learning model - acceptance differences between experts and novice. Eurasia Journal of Mathematics, Science and Technology Education. https://doi.org/10.12973/eurasia.2016.1517a

$\mathrm{Xu}$, H., Feng, J., \& Li, S. (2014). Users-orientated evaluation of building information model in the Chinese construction industry. Automation in Construction. https://doi.org/10.1016/j.autcon.2013.12.004 